\title{
Reografiar
}

\section{The quality of life among visitors of recreational parks: A case study of Recreational Parks in Temerloh Town, Pahang, Malaysia}

\author{
Oliver Ling Hoon Leh, Siti Nazurah Salehudin, Marlyana Azyyati Marzukhi, Qi Jie Kwong \\ Environmental \& Social Health Research Group, \\ Faculty of Architecture, Planning \& Surveying, \\ Universiti Teknologi MARA, Puncak Alam, Selangor, Malaysia
}

Correspondence: Oliver Ling Hoon Leh (email: oliverling.my@gmail.com)

Received: 20 June 2020; Accepted: 21 January 2021; Published: 27 February 2021

\begin{abstract}
Recreational parks are important in encouraging physical activities and social relationship among the community as well as to improve the quality of life (QoL) of the community through their participation in the parks. Quality of life can be incorporated into the ideas of expectation and satisfaction, which covers physical, social and health aspects. Participation in leisure or recreation activities is considered by many researchers as an essential component of an individual's sense of QoL. A study had been carried out in Temerloh town to study the QoL impact of the recreation parks. A questionnaire survey was carried out among the visitors to examine the expectation and satisfaction of respondents (visitors) on the three aspects of QoL, i.e. physical, social and health. As a result, the study found that respondents were having lower "satisfaction" scores as compared to the scores for "expectation" on average. It shows a low level of QoL for the study areas. Furthermore, the study also found that the satisfaction of respondents on physical aspects was positively and significantly correlated to the social aspects of QoL. Thus, the physical aspects of recreation parks were potentially impacting the social aspects of QoL among respondents who used the parks. It is suggested that recreational parks should be improved especially the physical aspects, i.e. safety and physical facilities for the purpose to increase the QoL of the users including the community interaction, family life and health.
\end{abstract}

Keywords: expectation, health, physical, quality, satisfaction, social.

\section{Introduction}

The recreational park or urban park refers to a public area that has a green area and equipped with facilities for people to do their recreational/leisure activities and engage with others socially (Nurul Shakila et al., 2018). Today, even though Malaysia is rapidly developing with various development projects, but the need for parks for people shall not be neglected. Unarguably, the purpose of parks 
is to encourage the social relationship among the community as well as to improve the quality of life (QoL) of the community through physical and social activities. Smith (2000) stated the definition of QoL usually incorporate ideas of satisfaction or dissatisfaction as well as happiness or unhappiness and associated with the general status of health and socio-economic background. Several studies have shown a positive relationship between leisure or recreation participation and QoL, including the benefits of relaxation, self-improvement, family functioning, and cultural awareness (Kara \& Demirci, 2010; Baker \& Palmer, 2006). Participation in leisure or recreation activities was considered by many researchers as an essential component of an individual's sense of wellbeing or QoL (Baker \& Palmer, 2006; Newman et al., 2014). In overseas publications, the importance of parks on the QoL was well-explained. However, it is lacking in local research. Thus, this article was prepared with the aim to discuss the impacts of Malaysian recreational parks on the QoL of the visitors (also the surrounding residents).

\section{Literature review}

\section{Quality of Life}

Quality of Life (OoL) can be defined as a social welfare component that covering all the important aspects of human life ranging from personal advances, nutrition, shelter, health, education, security, social stability, recreation, physical environment, transportation, arts and economy (Ahmad, 2005; Ling et al., 2018a; Nurul Shakila et al., 2018). It is involving individuals' perceptions of their position in life, inside the context of the culture and value systems at intervals which they live and in relevance their goals, expectations and concerns (WHO, 1994). QoL also can be understood as a movement or changes in society and the life of a situation which is considered unsatisfactory or less satisfactory to a better state of quality. When a society turned to a much better life, the QoL has been improved (Unit Perancang Ekonomi, 2002).

According to Szalai \& Andrews (1980), the most important things in providing a good QoL to people individually or community in a very specific way contains four aspects which are political, economic, social and educational. However, based on Boyer \& Savageau (1981), the elements of QoL are covering wider scopes which include the environment, health, housing, crime, transportation, recreation, arts, economy and education. To highlight, QoL does not only support the population through economic progress as a result of the method of life itself covers several different aspects of QoL that are social, psychological, cultural and environmental (Henderson, 1996).

In research, there are basically two views in measuring QoL, which are social indicators that consider the elites' valuation of what the individuals want, and standard quality of life that concern on what individuals need, to enhance their QoL (Mukherjee, 1989). For instance, research by Nur Farhana et al. (2018) was choosing nine (9) indicators to measure QoL, which are economic capacity, transportation, living condition, environment, social involvement, public safety, health and physical well-being, daily activities, as well as educational background.

\section{Recreational Park and QoL}

Several studies have shown a positive relationship between leisure or recreation participation and 
QoL (Baker \& Palmer, 2006). Researchers have identified many positive benefits of leisure participation, such as relaxation, meditation, self-improvement, gather with family and friends, enjoy the beauty of nature, cultural awareness and improve healthy lifestyle (Kara \& Demirci, 2010; Razak, Othman \& Nazir, 2016; Liu et al., 2017; Shamirah et al., 2020). As refer to Dolnicar et at. (2012), holidays affect individuals' QoL and the effect is of comparable importance to the domains of leisure and people.

Besides the social, psychological and cultural benefits of holiday or leisure activities on general community members, a study on a number of cancer patients was also showing improved personal health (physical as well as psychological), increased social effectiveness, personal identity and regained independence as the key health benefit of going on holiday or leisure activities (Hunter, 2003).

Furthermore, recreational area or more specific the green area is having an important role in the social, economic, cultural and environmental aspects of sustainable development as well as being an essential tool for improving the QoL, aesthetic value of an area, and providing services to communities such as recreational parks and rest areas. According to Ariane et al. (2005), training facilities, including parks could easily are associated with physical activity both for adults and for children. There are several psychological advantages to the visitors from the impact of the park a "natural environment" as an example, Ulrich and Addoms (1981) found that individuals gain nice advantages of psychological, additionally as a "feeling of open area," "change of scenery" and "a place to escape their lifestyle". Psychological benefit ranked a higher position in the interest of recreational and social aspects as related to the park (Ulrich and Addoms, 1981). Therefore, a park can also facilitate social interactions that are critical in maintaining social cohesion, pride and social capital (Ngesan et al., 2012).

Thus, a green area can promote the opportunity to recreate, to transform psychology and physical health of the human being, as the catalyst for social relations and even create educational opportunities among the users (Zhou, 2012). The green area is also contributing to the provision of places for social interaction apart from space for privacy and creating a distinctive community identity (Jusoh, et al., 2014).

Green areas have the potential to promote social well-being or QoL through social integration, establishing brotherhood, attitudes of engagement and support in society when carrying out any activity in green areas. For an ecologist and sociologist, human beings are conferred with the brain and thought which, it is thought to have a relationship with nature and only with this relationship, man will grow or grow normally (Jusoh, et al., 2014). As a result, by spending time in a green area can form a healthy mental, reducing stress and improving physical health (Jusoh, et al., 2014).

\section{Method and study area}

There are two (2) recreational parks in the Temerloh Town had been chosen as study areas for the purpose to identify the impacts of urban creational parks on the QoL of the visitors (also the surrounding residents), i.e. Taman Bandar Temerloh (Temerloh Urban Park) and Taman Awam Kubang Gajah (Kubang Gajah Public Park). The recreational parks are located side by side at the centre of Temerloh Town (Figure 1), which are adjacent to the commercial area, government buildings, school and residential areas. 


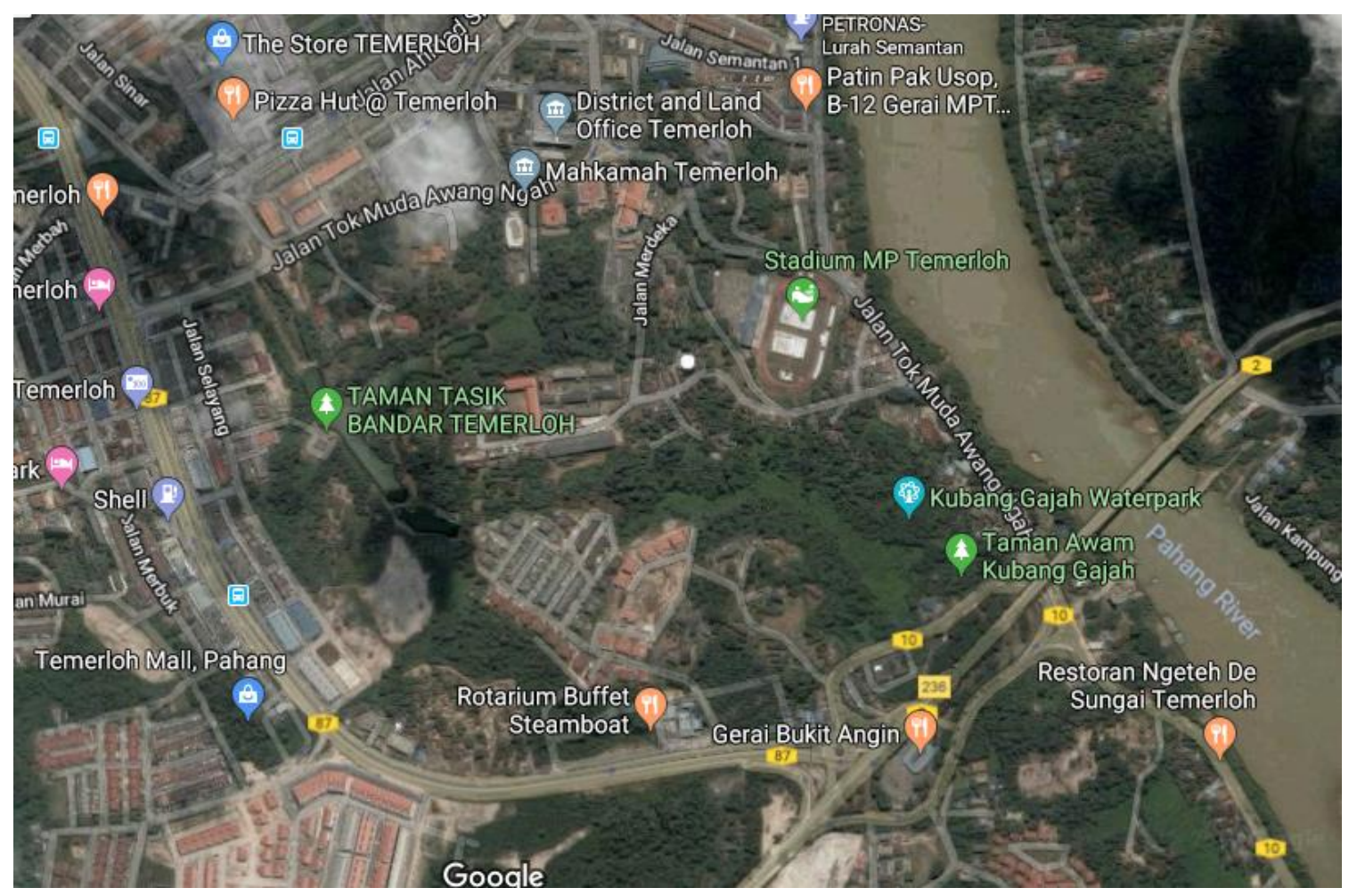

Source: Google Inc (2019)

Figure 1. Location of study areas

The recreational parks were equipped with various types of facilities for active and passive recreational activities. For instance, Taman Bandar Temerloh is equipped with view tower, amphitheatre, gazebos, benches, lake, children playground, skate park, outdoor gym/exercise equipment, jogging/cycling path and reflexology path. Meanwhile, Taman Awam Kubang Gajah is equipped with a football field, mini waterpark, petanque field, gazebos, benches, reflexology path, jogging/cycling path, outdoor gym/exercise equipment, children playground and others. Photos 1 to 3 show some of the physical facilities provided in the study areas. However, there were some problems faced by the parks, which were the cleanliness of toilets, illegal parking, facilities with poor maintenance and vandalism. 


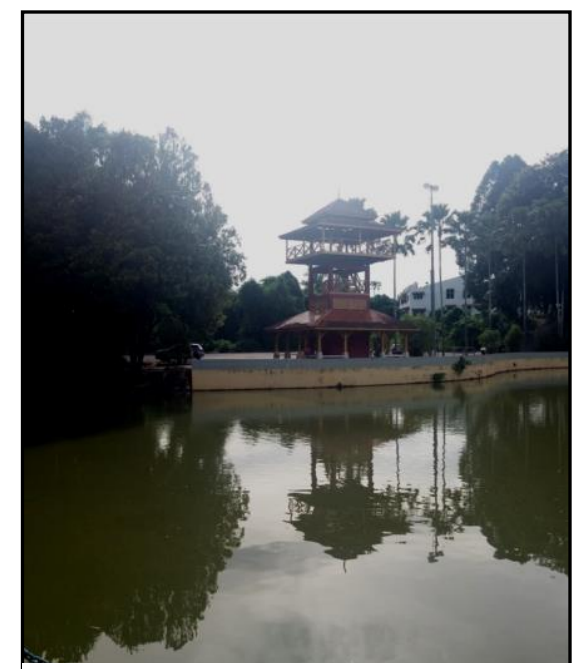

Photo 1: View tower \& lake in Taman Bandar Temerloh

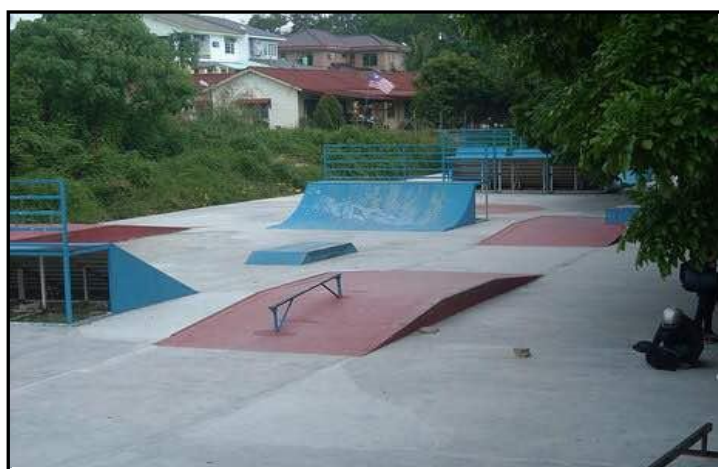

Photo 2: Skate park in Taman Bandar Temerloh

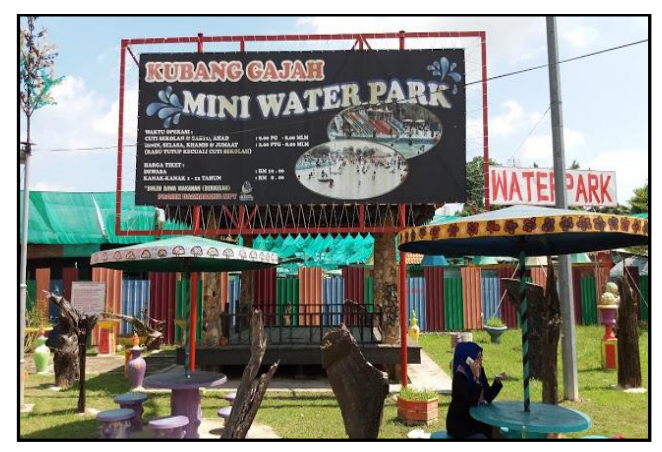

Photo 3: Mini Water Park in Taman Awam Kubang Gajah

The impact on QoL was studied based on the conceptual framework (Figure 2). The QoL was affected by expectation and satisfaction of parks' visitors on the physical aspects, social aspects and health aspects of QoL as a result of using the parks (Figure 2). The World Health Organization (WHO, 1994) outlined QOL as "individuals' perceptions of their position in life, inside the context of the culture and value systems at intervals which they live and in relevance their goals, expectations and concerns". Thus, a questionnaire survey was carried out to identify the perception of respondents (visitors of parks) on the expectation and satisfaction level of parks for the aspects and elements shown in Table 1.

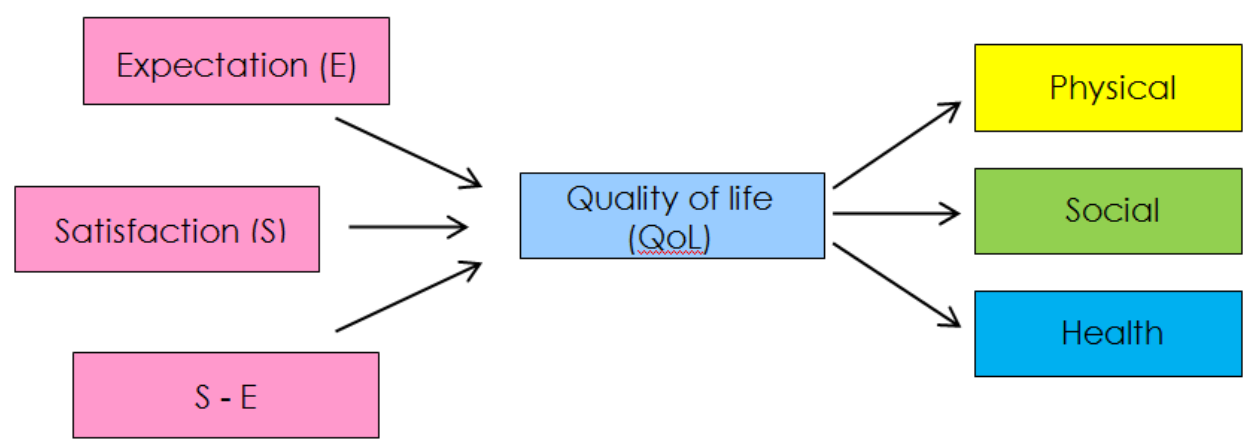

Figure 2. Conceptual framework 
Table 1: Elements for the three aspects of QoL

\begin{tabular}{lll}
\hline Aspects of QoL & \multicolumn{2}{c}{ Elements of QoL } \\
\hline Physical & 1. & Safety \\
& 2. & Facilities \\
Social & 1. & Community interaction \\
& 2. & Family life \\
Health & 1. & Suffering from chronic disease \\
\hline
\end{tabular}

In measuring the impact of the recreational parks on QoL, expectation and satisfaction of 111 visitors (as respondents) were collected for this questionnaire survey. A non-probability sampling technique, i.e. convenience sampling was applied for this questionnaire survey. Based on G-Power (Heinrich-Heine-Universität Düsseldorf, 2018), the required sample size for correlation analysis is 111 samples. This model (G-Power) had been used due to the unknown numbers of visitors for the study areas (the recreational parks). Thus, the required sample size was defined by the method of analysis. In general, the samples covered both male and female with a different social demographic background. Table 2 shows the general background of respondents in this study.

Table 2: Background of respondents

\begin{tabular}{lc}
\hline Variables & Percentage $(\mathbf{\%})$ \\
\hline Gender & \\
Male & 42.3 \\
Female & 57.7 \\
Ethnic & \\
Malay & 71.2 \\
Chinese & 18.9 \\
Indian & 7.2 \\
Others & 2.7 \\
Age & \\
10-19 years old & 9.0 \\
20-39 years old & 55.0 \\
40-59 years old & 28.8 \\
60 years old and above & 7.2 \\
\hline
\end{tabular}

\section{Results and discussion}

For the purpose to understand the impact of recreational parks on QoL, respondents' perception on their expectation (E) and satisfaction (S) on the physical, social and health aspects of QoL were identified through the questionnaire survey. The gap between satisfaction and expectation $(\mathrm{S}-\mathrm{E})$ was calculated to quantify the level of QoL of respondents for all the three aspects, i.e. physical, social and health. For the best scenario, satisfaction is higher than the expectation for the aspects of QoL. However, in this study, the mean scores for satisfaction were lower than the expectation for all the aspects of QoL. That means in average, respondents were expecting a higher level of quality for all the aspects as compared to their satisfaction on the existing quality of the study areas (recreational parks). Therefore, the QoL levels were low among the respondents (visitors of the parks), whereby the $\mathrm{S}-\mathrm{E}$ were in negative values (Table 3 ). 
As refer to the findings of the questionnaire survey, it is found that respondents were having higher expectation on the aspect of health with mean score 4.65 as compared to physical and social aspects with the mean score, not more than 4.35 (Table 3). In terms of satisfaction, health aspect also has the highest mean score value, 4.20 as compared to physical and social aspects with the mean score, not more than 3.91 (Table 3). By considering the gap between satisfaction (S) and expectation (E), it is found that physical aspects were having the largest " $\mathrm{S}-\mathrm{E}$ " value (-0.92 for safety and -1.10 for facilities) as compared to social and health aspects with the gaps, not more than -0.57 (Table 3). It means that among the three (3) aspects of QoL, respondents were having the lowest QoL for the physical aspects, and the highest QoL for the health aspect as the impact of using the parks. The results showed that the physical aspects of the study areas were low in quality and it contributed to the low level of QoL. However, QoL study at other park was showing the different result. For instance, QoL of a park in Shah Alam city shown highest mean scores for physical aspects (recreational facilities and activities) as compared to other aspects (Hazlina et al., 2017).

Table 3: Mean scores for the physical, social and health aspects of QoL

\begin{tabular}{lccccc}
\hline & \multicolumn{2}{c}{ Physical } & \multicolumn{2}{c}{ Social } & Health \\
& Safety & Facilities & Interaction & Family life & Chronic disease \\
\hline Expectation (E) & 4.24 & 4.23 & 4.27 & 4.35 & 4.65 \\
Satisfaction (S) & 3.32 & 3.13 & 3.70 & 3.91 & 4.20 \\
S - E & -0.92 & -1.10 & -0.57 & -0.44 & -0.45 \\
\hline
\end{tabular}

Note: Scale for scoring is ranging 1 to 5.

\section{Physical aspects of $Q o L$}

Among the 111 respondents (Tables 4 and 5), most of the respondents were expecting "acceptable" (68 and 64 respondents) and "good condition" (36 and 37 respondents) levels for the physical (safety and physical facility) aspects in the parks. However, the majority of respondents felt that they were only satisfied at the "less acceptable" level (57 and 72 respondents for safety and physical aspects respectively). It showed that the satisfaction level among respondents was lower than the expected level for the physical aspects. It showed that most of the respondents were still not satisfied with the safety and physical facility level of the parks. It is contributing towards the lower QoL among respondents due to the physical (safety and physical facility) aspects of parks. A study of KLCC park also found the importance of the sense of safety and security to the parks' users (Atefeh \& Norsidah, 2014).

Table 4: Respondents' expectation and satisfaction on the safety condition

\begin{tabular}{|c|c|c|}
\hline \multirow[t]{2}{*}{ Grading Scale } & \multicolumn{2}{|c|}{ The aspect of Safety (No. of Respondents) } \\
\hline & Expectation & Satisfaction \\
\hline Very Unacceptable & - & 2 \\
\hline Unacceptable & 2 & 8 \\
\hline Less Acceptable & 5 & 57 \\
\hline Acceptable & 68 & 41 \\
\hline Good Condition & 36 & 3 \\
\hline Mean & 4.24 & 3.32 \\
\hline Median & 4.00 & 3.00 \\
\hline Std. Deviation & 0.621 & 0.726 \\
\hline
\end{tabular}


Table 5: Respondents' expectation and satisfaction of physical facilities

\begin{tabular}{lcc}
\hline \multicolumn{1}{c}{ Grading Scale } & $\begin{array}{c}\text { The aspect of Physical Facilities (No. of Respondents) } \\
\text { Expectation }\end{array}$ & \multicolumn{2}{c}{ Satisfaction } \\
\hline Very Unacceptable & - & 2 \\
Unacceptable & 2 & 11 \\
Less Acceptable & 8 & 72 \\
Acceptable & 64 & 23 \\
Good Condition & 37 & 3 \\
Mean & $\mathbf{4 . 2 3}$ & $\mathbf{3 . 1 3}$ \\
Median & $\mathbf{4 . 0 0}$ & $\mathbf{3 . 0 0}$ \\
Std. Deviation & $\mathbf{0 . 6 5 6}$ & $\mathbf{0 . 6 8 9}$ \\
\hline
\end{tabular}

\section{Social aspects of $Q o L$}

For the aspects of social (Tables 6 and 7), most of the respondents were also expecting "acceptable" (61 and 69 respondents) and "good condition" (41 and 46 respondents) for the community interaction and family life due to the enjoyment of parks. It means respondents were looking for a good interaction among community members and good family life as the impact of taking activities in the parks. However, most of them only satisfied with the "acceptable" level for the social aspects (55 and 49 respondents respectively). It can be related to the physical quality of parks which was not achieving the expected level of respondents (Tables 4 and 5). Thus, the physical aspect did affect the satisfaction of respondents on the social aspects (community interaction and family life in the parks). It can be supported by the correlation analysis as discussed below.

Table 6. Respondents' expectation and satisfaction on community interaction

\begin{tabular}{lcc}
\hline \multicolumn{1}{c}{ Grading Scale } & $\begin{array}{l}\text { Community Interaction (No. of Respondents) } \\
\text { Expectation }\end{array}$ & $\begin{array}{c}\text { Satisfaction } \\
\text { Very Unacceptable }\end{array}$ \\
Unacceptable & 2 & - \\
Less Acceptable & 7 & 5 \\
Acceptable & 61 & 37 \\
Good Condition (good interaction) & 41 & 55 \\
Mean & $\mathbf{4 . 2 7}$ & 14 \\
Median & $\mathbf{4 . 0 0}$ & $\mathbf{3 . 7 0}$ \\
Std. Deviation & $\mathbf{0 . 6 6 0}$ & $\mathbf{4 . 0 0}$ \\
\hline
\end{tabular}

Table 7. Respondents' expectation and satisfaction of family life

\begin{tabular}{|c|c|c|}
\hline \multirow[t]{2}{*}{ Grading Scale } & \multicolumn{2}{|c|}{ Family life (No. of Respondents) } \\
\hline & Expectation & Satisfaction \\
\hline Very Unacceptable & - & 2 \\
\hline Unacceptable & 1 & 2 \\
\hline Less Acceptable & 5 & 29 \\
\hline Acceptable & 59 & 49 \\
\hline Good Condition (good family life) & 46 & 29 \\
\hline Mean & 4.35 & 3.91 \\
\hline Median & 4.00 & 4.00 \\
\hline Std. Deviation & 0.613 & 0.869 \\
\hline
\end{tabular}




\section{Correlation between physical and social aspects of $Q o L$}

By using the Spearman Correlation test, the analysis showed that satisfaction on social aspects was positively and significantly correlated (at 0.01 level) to the satisfaction on physical aspects of QoL (Table 8). It showed that lower the satisfaction of respondents on physical (safety and facilities) aspects was bringing down the satisfaction of respondents on the social aspects of QoL (family life and community interaction) while the respondents were using the facilities in the parks (study areas).

Table 8. Correlation between satisfaction on social aspects and satisfaction on the physical aspects

\begin{tabular}{lcc}
\hline \multirow{2}{*}{ Social aspects } & \multicolumn{2}{c}{ Physical aspects } \\
& Safety & Facilities \\
\hline Satisfaction (family life) & $\mathrm{r}=0.401$ & $\mathrm{r}=0.303$ \\
& $\mathrm{p}=0.000$ & $\mathrm{p}=0.001$ \\
Satisfaction (community interaction) & $\mathrm{r}=0.456$ & $\mathrm{r}=0.393$ \\
& $\mathrm{p}=0.000$ & $\mathrm{p}=0.000$ \\
\hline
\end{tabular}

\section{Health aspects of $Q o L$}

Based on the questionnaire survey, most of the respondents (90 respondents, Table 9) were expecting no chronic disease. However, in reality, there were 65 respondents only not suffering from any chronic disease. That means, there was a higher number of respondent suffering from chronic diseases as compared to their expectation (Table 9).

However, in general, most of the respondents (around two-third) can be considered as in good health, with no chronic disease (65 respondents), as compared to those with chronic disease (37 respondents). Healthy lifestyle especially the physical activity is contributing to the health of people. Previous research found that people actively engaged with physical activity can reduce the risk of chronic illness including cardiovascular disease and diabetes (Ling, et al., 2018b; Siti Nur Afiqah et al., 2015; Gadais et al., 2018; Masana et al., 2017). Physical activity is defined as any bodily movement produced by a contraction of skeletal muscles that increases energy expenditure above a basal level, which may include children's active play, running, dancing, gym exercise, and sports (Barton, 2009).

Based on the questionnaire survey, most of the respondents $(57.6 \%)$ were carrying out active activities in the parks, such as playing football, jogging and doing the gyms (Table 10). Meanwhile, there were $42.4 \%$ of respondents only carrying out passive activities in the parks, such as leisure, talking with friends, and sightseeing.

However, those who have frequently visited the parks consisted of $40.5 \%$ only from the total respondents. There were visiting the parks at least 3 times a week (Table 11). Most of the respondents $(59.5 \%)$ were only visiting the parks less than 3 times a week (Table 11). It might due to the lower level of satisfaction of respondents on the physical and social aspects of the parks (Table 3). Actually, involvement in active activities in parks should be encouraged through better quality of physical and social aspects of the parks. Research by Shamirah et al. (2020) at Changkat Public Park in Batu Gajah, Perak has also shown that the park quality affected the physical activity (healthy lifestyle) of most of the visitors. 
Table 9. Respondents' expectation and satisfaction of health (chronic disease)

\begin{tabular}{lcc}
\hline \multicolumn{1}{c}{ Grading Scale } & \multicolumn{2}{c}{ Health (No. of Respondents) } \\
Satisfaction & \\
\hline Hospitalised (chronic disease) & 2 & 2 \\
With chronic disease & 1 & 2 \\
(uncontrolled) & & \\
With chronic disease & 10 & 33 \\
(under controlled) & & \\
Not Sure & 8 & 9 \\
No chronic disease & 90 & 65 \\
Mean & $\mathbf{4 . 6 5}$ & $\mathbf{4 . 2 0}$ \\
Median & $\mathbf{5 . 0 0}$ & $\mathbf{5 . 0 0}$ \\
Std. Deviation & $\mathbf{0 . 8 2 7}$ & $\mathbf{1 . 0 4 3}$ \\
\hline
\end{tabular}

Table 10. Types of activities among respondents

\begin{tabular}{lrrr}
\hline \multicolumn{1}{c}{ Age } & \multicolumn{3}{c}{ Type of Activity (No. of Respondents) } \\
& Active & Passive & \multicolumn{1}{c}{ Total } \\
\hline 10-19 years old & $\mathbf{7}$ & 3 & 10 \\
$\mathbf{2 0 - 3 9}$ years old & $\mathbf{3 1}$ & $\mathbf{3 0}$ & $\mathbf{6 1}$ \\
40-59 years old & $\mathbf{2 1}$ & 11 & 32 \\
$>$ 60 years old & $\mathbf{5}$ & 3 & 8 \\
Total & $\mathbf{6 4}$ & $\mathbf{4 7}$ & $\mathbf{1 1 1}$ \\
Percentage $(\%)$ & $\mathbf{5 7 . 6 \%}$ & $\mathbf{4 2 . 4 \%}$ & $\mathbf{1 0 0 . 0 \%}$ \\
\hline
\end{tabular}

Table 11. Frequency of visit to parks (study areas)

\begin{tabular}{|c|c|c|c|c|}
\hline \multirow{2}{*}{ Age } & \multicolumn{3}{|c|}{$\begin{array}{l}\text { Frequency of visit in a week } \\
\text { (No. of Respondents) }\end{array}$} & \multirow[t]{2}{*}{ Total } \\
\hline & $<3$ times & $3-5$ times & $>5$ times & \\
\hline 10-19 years old & 2 & 2 & 6 & 10 \\
\hline 20-39 years old & 45 & 13 & 3 & 61 \\
\hline 40-59 years old & 16 & 12 & 4 & 32 \\
\hline$>60$ years old & 3 & 2 & 3 & 8 \\
\hline Total & 66 & 29 & 16 & 111 \\
\hline Percentage (\%) & $59.5 \%$ & $26.1 \%$ & $14.4 \%$ & $100.0 \%$ \\
\hline
\end{tabular}

\section{Conclusion}

To conclude, a successful or functional recreational park should be well-equipped with good facilities, safe, able to increase interaction among the visitors, can improve the family life, and able to maintain the good health as a result of carrying out activities in the parks for the better QoL. Besides the planning, designing and constructing good recreational parks with good landscape elements including physical facilities (Rosniza Aznie \& Nur Efazainiza, 2019), cooperation from visitors or the public in maintaining the high standard of facilities and cleanliness is crucial. As mentioned by Farah Ayuni (2015), the sustainability of urban and the environment required public participation which comes internally with their attitude and culture towards human 
and environment. Based on this research, people are putting a high expectation on these aspects where they are visiting the recreational parks. The mean scores for expectation were more than 4.2 (scale of scoring is ranging 1 to 5). On the other side, the satisfaction levels were lower than 4.0 except for the health aspect. By carrying out the correlation analysis, the study found that the satisfaction of respondents on physical aspects (safety and physical facilities) was positively and significantly related to the social aspects of QoL. It showed that the physical aspects of parks were affecting the social satisfaction of respondents on the aspects of QoL. It is suggested that the physical aspect of recreational parks can be improved for the purpose to increase the QoL of the users and the involvement in active physical activities for a better health level. To complement the physical aspects of a park, the importance of social environment of a park (such as the companionship and presence of friends) should not be ignored to attract people to use a park as referring to the research finding by Zoreh and Melasutra (2016). These social environmental elements also increase a sense of safety of the park (one of the important physical aspects).

\section{Acknowledgement}

The authors would like to thank Universiti Teknologi MARA (UiTM) for the support and partly funding the study and publication through the BESTARI research grant (600-IRMI/MYRA 5/3/BESTARI (008/2017)). The authors are also thankful to all the departments, organisations, and individual who had contributed to this study.

\section{References}

Ahmad, A. (2005). Kualiti hidup dan pengurusan persekitaran di Malaysia, UKM.

Ariane L, Mowen A.J., Cohen, D.A. (2005). The Significance of Parks to Physical Activity and Public Health. American Journal of Preventive Medicine, 28(2), 159-168.

Atefeh, A. and Norsidah, U. (2014). The impact of physical features on user attachment to Kuala Lumpur City Centre (KLCC) Park, Malaysia. Geografia-Malaysia Journal of Society and Space, 10(3): 44-59.

Baker, D.A., \& Palmer, R.J. (2006). Examining the Effects of Perceptions of Community and Recreation Participation on Quality of Life. Social Indicators Research, 75(3), 395-418.

Barton, H. (2009). Land use planning and health and well-being. Land use policy, 26, S115-S123.

Boyer \& Savageau. (1981). Places Rated Almanac. New York, Rand McNally.

Dolnicar, S., Yanamandram, V.K., Cliff, K. (2012). The Contribution of Vacations to Quality of Life. Annals of Tourism Research, 39(1), 59-83.

Farah Ayuni, S. (2015). Urban sustainability in Barcelona: Living and learning the experience. Procedia - Social and Behavioral Sciences, 168, 381-388.

Gadais, T., Boulanger, M., Trudeau, F., Rivard, M.C. (2018). Environments favorable to healthy lifestyles: A systematic review of initiatives in Canada. Journal of Sport and Health Science, 7(1), 7-18. doi: 10.1016/j.jshs.2017.09.005

Google Inc. (2019). Google Maps. Retrieved from https://www.google.com/

Hazlina, H, Nurul Shakila, K., Nurul Faizah, B. (2017). People in city: the relation of urban park and the quality of life. Environment-Behaviour Proceedings Journal, 2(6): 311-318. 
Heinrich-Heine-Universität Düsseldorf. (2018). G*Power: Statistical Power Analyses for Window and Mac. Retrieved from http://www.psycho.uni-duesseldorf.de/abteilungen/aap/gpower3 Henderson, G. (1996). Human relations issues in management. Westport, CT., Quorum Books.

Hunter. (2003). The Connection Between Psychological and Physical Health. Retrieved from https://www.cqu.edu.au/data/assets/pdf_file/0006/57282/The_Connection_between_Psyc hological_and_Physical_Health_slides_for_webinar_pdf.pdf

Jusoh, H., Ahmad, H., Buang, A., Zoolberi, F. A., Nik Muhammad, N. M., Yusop, N. A., Er, A. C., \& Mahmud, M. (2014). Impak kawasan hijau terhadap persekitaran sosial komuniti Putrajaya. Geografia-Malaysia Journal of Society and Space, 10(8), 26-39.

Kara, F., \& Demirci, A. (2010). Spatial analysis and facility characteristics of outdoor recreational areas in Istanbul. Environ Monit Assess, 164(1-4), 593-603.

Ling, O.H.L., Norseha, M.M., Nur Asma, A. H., Marlyana, A.M., \& Jamalunlaili A. (2018a). Quality of life among residents in a sub-urban area. Case study: Puncak Alam, Selangor, Malaysia. IOP Conference Series: Earth and Environmental Science, 117(1).

Ling, O.H.L., Nur Hidayah, S., Marlyana, A.M., \& Sharifah Zannierah, S.M. (2018b). Healthy lifestyle of urban residents. Case study: Sri Pahang public housing, Bangsar, Kuala Lumpur, Malaysia. Planning Malaysia, 16(3), 1-12.

Liu, H., Li, F., Li, J., \& Zhang, Y. (2017). The relationships between urban parks, residents' physical activity, and mental health benefits: A case study from Beijing, China. Journal of Environmental Management, 190, 223-230.

Masana, L., Ros, E., Sudano, I., \& Angoulvant, D. (2017). Is there a role for lifestyle changes in cardiovascular prevention? What, when and how? Atherosclerosis Supplements, 26(2017), $2-15$.

Mukherjee, R. (1989). The quality of life. New Delhi, Sage Publications.

Newman, D., Tay, L., \& Diener, E. (2014). Leisure and subjective well-being: A model of psychological mechanisms as mediating factors. Journal of Happiness Studies, 15(3), 555-578.

Nur Farhana, R., Noor Suzilawati, R. \& Mariana, M.O. (2018). Perception of quality of life among community in Selangor. Planning Malaysia Journal, 16(2): 12-20.

Nurul Shakila, K., Nurul Faizah, B., \& Hazlina, H. (2018). Improving quality of life through recreational behaviour in urban park. Asian Journal of Quality of Life, 3(13), 80-88.

Ngesan, M.R., Abdul Karim, H., \& Zubir, S.S. (2012). Human Behaviour and Activities in Relation to Shah Alam Urban Park during Nighttime. Procedia Social and Behavioral Sciences, 68, 427-438.

Razak, M. A. W. A., Othman, N., \& Nazir, N. N. M. (2016). Connecting people with nature: Urban park and human well-being. Procedia-Social and Behavioral Sciences, 222, 476-484.

Rosniza Aznie, C.R. \& Nur Efazainiza, A.B. (2019). Analisis tahap kepuasan pengunjung di taman rekreasi awam Sabah. Geografia-Malaysia Journal of Society and Space, 15(4): 336-349.

Shamirah, R., Ling, O.H.L., Nurhazlin Amira, M.A., \& Marlyana Azyyati, M. (2020). Relationship between quality of urban parks and physical activity: A case study in Changkat Public Park, Batu Gajah, Perak. Planning Malaysia Journal, 18(4): 158-172.

Siti Nur Afiqah, M.M., Ling, OHL, Dasimah, O., \& Subramaniam, K. (2015). Theoretical review on environmental health in relation to neighbourhood planning and human physical activity. Procedia - Social and Behavioral Sciences, 201, 325-332. 
Smith, A. (2000). Researching quality of life of older people: concept, measures and findings. Working Paper No. 7, Centre for Social Gerontology, Keele University. Retrieved from https://www.keele.ac.uk/csg/downloads/centreworkingpapers/research_quality.pdf

Szalai, A. \& Andrews, F.M. (1980). The Qualiy of life- Comparative studies, USA, Sage Studies in International Sociology.

Ulrich, R. S., \& Addoms, D. L. (1981). Psychological and recreational benefits of a residential park. Journal of Leisure Research, 13, 43-65.

Unit Perancang Ekonomi (2002). Kualiti hidup Malaysia 2002, Kuala Lumpur.

World Health Organization Quality of Life Group (1994). Development of the WHOQOL: Rationale and Current Status. International Journal of Mental Health, 23(3), 24-56.

Zhou, X., Rana MMP (2012). Social benefits of urban green space: A conceptual framework of valuation and accessibility measurements. Management of Environmental Quality: An International Journal, 23(2), 173-189.

Zohreh, M. \& Melasutra, M.D. (2016). Adolescent use of urban parks and their social environment consequences. Geografia-Malaysia Journal of Society and Space, 12(11), 123-136. 